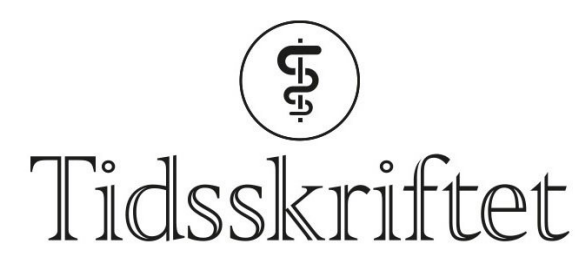

DEN NORSKE LEGEFORENING

\title{
Finn Ørnulf Winther
}

MINNEORD

MORTEN BOYSEN

KJELL BRØNDBO

ROLF HAYE

HENRIK LINDEMAN

KETIL NATVIG

TERJE OSNES ULF ZÄTTERSTÖM

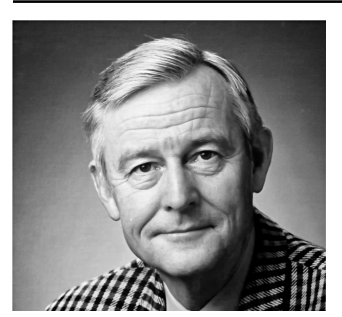

Vår gode venn og sjef i mange år, Finn $\emptyset$. Winther ble født i Oslo 27. desember 1932 og døde 10. september 2018 etter noe tids sykdom. Han tok medisinsk embetseksamen i 1957 og ble i 1964 spesialist i øre-nese-hals-sykdommer. I 1970 disputerte han med en avhandling om virkningen av strålebehandling på det indre øret. Han hadde en betydelig vitenskapelig produksjon samt en rekke artikler av mer generell art.

I 1974 ble han overlege og professor ved Øre-nese-hals-avdelingen på Ullevål sykehus. Fra 1976 var han avdelingsoverlege og professor I ved Rikshospitalets Øre-nese-hals-avdeling. Han pensjonerte seg i 2002.

Finn hadde en lang rekke faglige og administrative verv. I årene 1974-75 var han formann i den norske Øre-nese-hals-foreningen, der han senere ble æresmedlem. I tillegg var han prodekanus i 3 år og styremedlem ved Rikshospitalet i 4 år. Han var formann i den Regionale forskningsetiske komite ved Helse $\emptyset \emptyset r$ i 8 år og arbeidet med utforming av komiteens regelverk. 84 år gammel fullførte han sitt siste akademiske oppdrag som ph.d.veileder innenfor feltet medisinsk etikk. Med sitt brede kontaktnettverk har han for mange vært behjelpelig med å knytte faglige kontakter, finansiering av studieopphold i utlandet og økonomisk støtte til deltagelse på konferanser, samt utstyr til vitenskapelige prosjekter.

Finn var en prinsippfast leder, alltid ryddig og opptatt av nøktern bruk av tilgjengelige 
ressurser. I alle år var undervisning en av hans hjertesaker, og tilbakemeldinger fra studenter var alltid gode. Som lege var Finn spesielt engasjert i diagnostikk og behandling av pasienter med kreft i øre-nese-hals-området. Han var en kunnskapsrik og omtenksom doktor som ga pasientene trygghet.

Hans vennlige og kultiverte vesen skapte en varm og tillitsfull atmosfære på avdelingen. De som fikk sin spesialistutdannelse, og alle andre som har vært ansatt, opplevde at avdelingen var en god og trivelig arbeidsplass. Dette reflekteres i de årlige sammenkomster der det feires vennskap og gode minner fra vår tid på Rikshospitalet.

Bekkelagsgutten benyttet Østmarka sommer som vinter. Fra hytta i Hallingdal eller på Hardangervidda nøt han hver høst jaktopplevelser med «jegerklubben». Sommerne tilbrakte han på Askerøya ved Tvedestrand, der flere av hans kullkamerater også hadde hytte.

Det er i takknemlighet vi tar avskjed med Finn. Våre varmeste tanker går til Dagrun, Finn Eirik og Mathilde.

Publisert: 8. april 2019. Tidsskr Nor Legeforen. DOI:10.4045/tidsskr.19.0039

(C) Tidsskrift for Den norske legeforening 2020. Lastet ned fra tidsskriftet.no 